\title{
Adherence to Antiretroviral Therapy and Associated Factors among People Living with HIV/AIDS in Hara Town and Its Surroundings, North-Eastern Ethiopia: A Cross-Sectional Study
}

\author{
Tesfaye Aychew Legesse ${ }^{1}$, Melese Abate Reta ${ }^{2 *}$
}

\section{OPEN ACCESS}

Citation: Tesfaye Aychew Legesse, Melese Abate Reta. Adherence to Antiretroviral Therapy and Associated Factors among People Living with HIV/AIDS in Hara Town and Its Surroundings, North-Eastern Ethiopia: A Cross-Sectional Study. Ethiop J Health Sci. 2019; 29(2):299.

doi:http://dx.doi.org/10.4314/ ejhs.v29i2.2

Received: April 13, 2018

Accepted: July 15, 2018

Published: May 1, 2019

Copyright: (C) 2019 Tesfaye Aychew Legesse, et al. This is an open access article distributed under the terms of the Creative Commons Attribution License, which permits unrestricted use, distribution, and reproduction in any medium, provided the original author and source are credited.

Funding: Nil

Competing Interests: The authors declare that this manuscript was approved by all authors in its form and that no competing interest exists.

Affiliation and Correspondence:

${ }^{1}$ Department of Nursing, Faculty of Health Sciences, Woldia University; P.O. Box 400; Woldia, Ethiopia ${ }^{2}$ Department of Medical Laboratory Science, Faculty of Health Sciences, Woldia University; P.O. Box 400; Woldia, Ethiopia

*Email: melese1985@gmail.com

\begin{abstract}
BACKGROUND: Adherence is the most important factor in determining Antiretroviral Therapy (ART) treatment success and long-term viral suppression. Nonadherence to ART led to the human Immunodeficiency Virus (HIV) related morbidity and mortality. Moreover, it intensifies the risk of the emerging drug resistant HIV strains. This study aimed to assess the level of ART adherence and to identify its predictive associated factors among people living with HIV/AIDS in Hara Town and its surroundings, North-Eastern Ethiopia.

METHODS: An institutional facility based cross-sectional study was conducted from April-May 2017. A total of 454 individuals were on ART follow-up in the selected ART-clinic, and only 418 patients were recruited. Bivariate and multivariate logistic regression analyses were carried out to identify associated factors. Odds ratio and 95\% Confidence Interval (CI) were calculated to determine the level of significance.

RESULTS: The level of ART adherence in the study setting was 300 (71.8\%). Participants who had not disclosed their HIV status to their families were $88 \%$ less likely to adhere to their ART medication than those who had disclosed their HIV status ((Odds ratio (OR): 0.12, 95\%CI:0.05-0.58; $p<0.001)$. On the other hand, participants who had not encountered drug side effects were 2.69 times more likely to adhere to their ART medication than those who had ever encountered drug side effects (OR: 2.69, 95\%CI:1.27-5.05; $p<0.001)$.

CONCLUSION: A very low level of ART adherence was shown in the study population. It was below the recommended good adherence standard. Therefore, patients should get adequate and comprehensive ART adherence counselling before initiation ART treatment and during the follow-up time.

KEYWORDS: Adherence, ART, HIV/AIDS, Associated factors, Hara Town, Ethiopia
\end{abstract}




\section{INTRODUCTION}

HIV/AIDS has continued as a leading public health problem globally. Particularly, low income countries such as sub-Saharan African countries are challenged with a widespread of the virus and socio-economic crises due to the disease $(1,2)$. Globally, in the previous era, many efforts had been made to fight against the worldwide HIV epidemic $(3,4)$. Accessibility of the ART treatment program had scaled-up (3). Hence, almost 10 million people had received the treatment by the end of 2012 (5). Accordingly, the rate of new infections and HIV/AIDS related morbidity and mortality declined significantly (3, 4). The scaled-up accessibility of ART treatment saved around 2.5 million lives from HIV-related deaths in developing countries, since 1995 (2).

ART treatment can suppress the viral replication, enhance immunological status, can reduce HIV transmission to uninfected people, and increase patients' life expectancy (6). With the availability of free ART treatment, the cost of ART, and related care is no longer adequate for treatment success and HIV-related mortality reduction $(7,8)$. Although efforts such as improving patients' awareness to seek treatment and when to initiate therapy, supporting continuity care, promoting and ensuring high ART adherence rate are vitally important (9).

The level of adherence to ART can vary based on population context, and moreover, it is affected by individual, service, and therapyrelated factors such as substance abuse, psychiatric problems, inability to disclose HIV status, lack of psychosocial support, stigma, drug side effect, pill burden, poor quality service delivery, and unexplained treatment cost $(10,11)$.

In Ethiopia, HIV epidemic is continuing to be a threat to the lives of many productive age groups (12). In 2007, it was estimated that 977,394 people lived with the virus, and this would result in a total of 71,902 HIV-related deaths. In the same year, the prevalence of HIV in Ethiopia was estimated to be $2.1 \%$ (12). However, the national HIV prevalence in 2014 was $1.14 \%$ (13). The advent of ART treatment in Ethiopia improved the quality of life for HIV-positive people and increased their life expectancy. Since Ethiopia's ART program began in 2003, a total number of 210,637 people started treatment in 481 facilities throughout the country. ART service expansion was recent and fast from only four facilities in 2003 to 481 in 2009 (14).

The ART adherence is now well understood as the most important determinant (15), and it is the 'Achilles heel' of ART treatment success (16, 17). Poor adherence can lead to preventable HIVrelated deaths. Moreover, it increases the risk of the emerging-drug resistant HIV strains $(16,18)$. Hence, educating and sustaining ART treatment adherence to the HIV positive individual is the important component which needs public health efforts (19). Due to many factors, a high number of HIV positive individuals are still dropping out from their treatment follow-up $(5,20)$.

A recent study has shown that the emergence of drug-resistant HIV strains in 'ART-naive people' is increasing (21). According to a World Health Organization (WHO) survey study in 12 developing countries in 2012, the HIV drug resistance rate among people starting ART ranged from $4.8 \%$ in 2007 to $6,8 \%$ in 2010 (22). Hence, "attention to and strengthening of adherence throughout the entire course of ART comprises an essential part of any successful treatment programme and should be built into the countryspecific program" (20). Although the magnitude of HIV at the study area was not known, the number of people who were registered to get HIV care and treatment was increasing, and there is limited information about the ART adherence level of people living with HIV/AIDS. Moreover, most peoples living in the study are pastoral and agro-pastorals. Hence, many factors might hinder them to adhere to their ART medications. Currently, the prevalence of HIV is increasing in the rural community. However, regional and the national HIV/AIDS prevention and control programme is unable to reach to investigate the magnitude of the disease, health service quality, individuals' ART adherence level, and their social and behavioural factors that hinder their ART treatment seeking behaviour. Many kinds of research are conducted in well-established towns

DOI: http://dx.doi.org/10.4314/ejhs.v29i2.2 
where most aware individuals about HIV/AIDS live. Therefore, this study was aimed to assess the level of adherence to ART treatment and its associated factors in Hara Town and its surroundings, North-Eastern Ethiopia.

\section{METHODS AND MATERIALS}

Settings: The study was done in the ART Unit of Hara Health Center. Hara is in the eastern part of the Amhara Region in North Wollo Zone. It is located at $383 \mathrm{~km}$ from the regional capital city, Bahir Dar, and $543 \mathrm{~km}$ from Addis Ababa. The town had a total population of 28,096 , (14188 males and 13,908 females). There was one ART clinic, 7 health posts, and 5 private clinics in the town. During this study piloted, there were a total of 454 HIV positive people who were on ART treatment follow-up. Four hundred eighteen patients were enrolled in this study.

Study design and period: An institutional facility based cross-sectional study was conducted from April to May 2017 to assess the level of adherence to ART and its associated factors among HIV positive individual in Hara Town and its surroundings, North-Eastern Ethiopia.

Study population and eligibility criteria: All HIV positive adults ( $\geq 18$ years old) who were currently on Highly Active Antiretroviral Therapy (HAART) follow-up at least for 3 months and had no difficulty to communicate were enrolled in this study. However, those patients who were seriously ill during data collection, and those who were under 18 years of age were excluded.

Sample size: Single population proportion formula was used to calculate the sample size. We considered the proportion $(\mathrm{P})$ of good adherence from a previous study $85.3 \%$ (10), the margin of error $5 \%$ at $95 \%$ confidence interval. Therefore, the final sample size was 193. However, there were a total of 454 adults who were on ART treatment follow-up in the study setting (ARTclinic); hence, all eligible study subjects were included.

Data collection procedures: A structured questionnaire was used as a data collection tool. We adapted the questionnaire partly from the AIDS Clinical Trial Group (ACTG) (23), adherence baseline and follow-up questionnaires. Pilot study was conducted on $5 \%$ of the total sample size at Kobo Health Center to check the validity of the questionnaire. The questionnaire includes information on socio-demographics, individual characteristics, and health and economic status of the respondents. The English version of the questionnaire was translated into local language (Amharic) for ease of understansing and it was translated back into the English language to check content validity. Two diploma nurses performed the interview and the data collection using the face-to-face interview method. Training was given to data collectors about the objectives of the study, and how they could approach the patients to obtain their confidentiality. Written and verbal consent was obtained from the study participants after the objectives of the study were explained. Patients' clinical data such as WHO clinical stage and the CD4 counts were retrieved from their medical record registration book at the ART clinic. An antiretroviral therapy adherence level was calculated based on the patients' report of seven days recall of missed doses before the interview date.

Data analysis: All the collected data were entered into EPI-Data 3.1 statistical software to code and edit errors, and then transferred into SPSS version 20.0 for analysis. The data were calculated and presented using descriptive statistics. Multivariate logistic regression analysis was performed to identify and check the associated risk factors to adherence. Odds ratio with $95 \% \mathrm{CI}$ was calculated, and independent variables with $p$-values of less than 0.05 in multivariate logistic regression analysis were considered significantly associated with adherence.

\section{Definition of operational term}

Adherence: Adherence is defined as good if it is $\geq 95 \%$ ( $<2$ doses of 30 doses or $<30$ doss of 60 doses is missed) as documented by ART healthcare provider. It is poor if it is between 85$94 \%$ (3-5 doses of 30 doses or 3-9 doses of 60 doses is missed) as documented by the ART healthcare provider.

Ethical consideration: Ethical approval letter was obtained from the institutional Research Review Committee of Health Sciences Faculty, Woldia University (No: 18/FHS/RERC/2017). Official permission letter was obtained from North Wollo 
Zone Health Department and Hara Health Center. The objective of the study was explained to all study subjects to obtain their verbal or written consent before the interview. Participants were informed that they had the full right to discontinue participating in the study if they felt discomfort. They were also assured that all the data provided by them would be kept confidential. In addition, no personal identifiers were used.

\section{RESULTS}

Socio-demographic characteristics: Out of a total of 454 study participants, 418 people living with HIV and currently on ART follow-up were enrolled in the analysis. The response rate was $92.1 \%$. Thirty-six cases were excluded because they were less than 18 years old. Of the total 418 participants, $246(58.9 \%)$ were females. The mean age of the study participants was 38.17 years while $36.6 \%$ of them were between the ages of $25-34$ years. Of the total, $35.9 \%$ were married. The majority, (69.4\%) of the study participants were illiterate. Two hundred twenty-seven $(54.3 \%)$ of them were farmers. The majority, 332 (79.4\%) did not get support from their family members to take their medication timely (Table 1).

Table 1: Socio-demographic characteristics of the study participants in Hara Town and its surroundings, April to May $2017(\mathrm{n}=418)$

\begin{tabular}{|c|c|c|c|}
\hline \multicolumn{2}{|c|}{ Attributes } & \multirow{2}{*}{$\begin{array}{c}\mathbf{N} \\
172\end{array}$} & \multirow{2}{*}{$\begin{array}{r}\% \\
41.1\end{array}$} \\
\hline Sex & Male & & \\
\hline \multirow{5}{*}{ Age (year) } & Female & 246 & 58.9 \\
\hline & $18-24$ & 22 & 5.3 \\
\hline & $25-34$ & 153 & 36.6 \\
\hline & $35-44$ & 140 & 33.5 \\
\hline & $\geq 45$ & 103 & 24.6 \\
\hline \multirow[t]{4}{*}{ Marital status } & Married & 150 & 35.9 \\
\hline & Divorced/ separated & 185 & 44.3 \\
\hline & Single & 67 & 16 \\
\hline & Widowed & 16 & 3.8 \\
\hline \multirow[t]{4}{*}{ Educational status } & Illiterate & 290 & 69.4 \\
\hline & Can read and write & 54 & 12.9 \\
\hline & Elementary & 61 & 14.6 \\
\hline & Secondary school $\&$ above & 13 & 3.1 \\
\hline \multirow[t]{2}{*}{ Residence } & Urban & 278 & 66.5 \\
\hline & Rural & 140 & 33.5 \\
\hline \multirow[t]{2}{*}{ Religion } & Orthodox & 58 & 13.9 \\
\hline & Muslim & 360 & 86.1 \\
\hline \multirow[t]{5}{*}{ Occupation } & Merchant & 38 & 9.1 \\
\hline & Housewife & 99 & 23.7 \\
\hline & Farmer & 227 & 54.3 \\
\hline & Government employ & 16 & 3.8 \\
\hline & Other* & 38 & 9.1 \\
\hline \multirow[t]{2}{*}{ Distance from the health facility } & $<10 \mathrm{~km}$ & 268 & 64.1 \\
\hline & $\geq 10 \mathrm{~km}$ & 150 & 35.9 \\
\hline \multirow[t]{3}{*}{ Monthly income ${ }^{\#}$} & $\leq 500$ & 287 & 68.7 \\
\hline & $501-999$ & 96 & 22.9 \\
\hline & $\geq 1000$ & 35 & 8.4 \\
\hline \multirow[t]{2}{*}{ Getting support } & Yes & 86 & 20.6 \\
\hline & No & 332 & 79.4 \\
\hline
\end{tabular}

\# Exchange rate $1 \mathrm{USD}=27.22$ Ethiopian Birr; * students, daily laborer 
Clinical and Behavioural Characteristics of the respondents: Two hundred $(47.8 \%)$ of the participants were at WHO clinical stage III. Two hundred thirty-six $(56.5 \%)$ of them had a baseline CD4 count between 200-499cells $/ \mathrm{mm}^{3}$ while $61.7 \%$ had a CD4 count between 200-499 during the antiretroviral treatment initiation time, and $55 \%$ had the CD4 count of $\geq 500$ cells $/ \mathrm{mm}^{3}$ during the interview. Three hundred ninety-two (93.8\%) of the respondents reported that they experienced drug side effect to ARV (antiretroviral) drugs; while, $93(22.2 \%)$ had histories of opportunistic infections. Of the total respondents, 361 (86.4\%) did not disclose their HIV status to their relatives (Table 2).

Table 2: Clinical and behavioural characteristics of the study participants in Hara Town and its surroundings, April to May $2017(\mathrm{n}=418)$

\begin{tabular}{|c|c|c|c|}
\hline \multicolumn{2}{|l|}{ Attributes } & \multirow{2}{*}{$\begin{array}{l}\mathbf{N} \\
51\end{array}$} & \multirow{2}{*}{$\begin{array}{l}\% \\
12.2\end{array}$} \\
\hline WHO clinical stage at the start of ART & Stage I & & \\
\hline & Stage II & 108 & 25.8 \\
\hline & Stage III & 200 & 47.8 \\
\hline & Stage IV & 59 & 14.1 \\
\hline \multirow[t]{3}{*}{ Baseline CD4 count } & $<200$ & 74 & 17.7 \\
\hline & $200-499$ & 236 & 56.5 \\
\hline & $\geq 500$ & 108 & 25.8 \\
\hline \multirow[t]{3}{*}{ CD4 count at the start of treatment } & $<200$ & 73 & 17.5 \\
\hline & $200-499$ & 258 & 61.7 \\
\hline & $\geq 500$ & 87 & 20.8 \\
\hline \multirow[t]{2}{*}{ Current CD4 count } & $<500$ & 188 & 45 \\
\hline & $\geq 500$ & 230 & 55 \\
\hline Encountered drug side effect in relation to & Yes & 392 & 93.8 \\
\hline ART & No & 26 & 6.2 \\
\hline \multirow[t]{2}{*}{ History of opportunistic infections (OIs) } & Yes & 93 & 22.2 \\
\hline & No & 325 & 77.8 \\
\hline Using memory aids as time reminder to take & Yes & 153 & 36.6 \\
\hline medication timely & No & 265 & 63.4 \\
\hline History of using an active substance like & Yes & 29 & 6.9 \\
\hline alcohol & No & 389 & 93.1 \\
\hline \multirow[t]{2}{*}{ Disclose HIV status for families } & Yes & 57 & 13.6 \\
\hline & No & 361 & 86.4 \\
\hline
\end{tabular}

The adherence measurement was calculated based on the respondents' self-report. In this study, of the total participants, only $71.8 \% \quad(95 \% \mathrm{CI}$ : $70.8 \%-74.4 \%)$ reported to have an adherence level of $\geq 95 \%$ in seven days before the interview.
The adherence level of ART in the previous three days prior to the data collection date was $82.5 \%$. The majority of the respondents with poor adherence, 63 (53.4\%) had reported that they forget to take their medication timely (Table 3).

DOI: http://dx.doi.org/10.4314/ejhs.v29i2.2 
Table 3: Study participants' adherence to ARV drugs at Hara Town and its surroundings, Ethiopia, April to May $2017(\mathrm{n}=418)$

\begin{tabular}{|c|c|c|c|}
\hline \multicolumn{2}{|l|}{ Attributes } & $\mathbf{N}$ & $\%$ \\
\hline \multirow[t]{2}{*}{ Taking other medication in addition to ARV drugs } & Yes & 29 & 6.9 \\
\hline & No & 389 & 93.1 \\
\hline \multirow{2}{*}{$\begin{array}{l}\text { How did you take ARV drug doses in the last } 7 \\
\text { days? }\end{array}$} & Missed & 118 & 28.2 \\
\hline & Not missed & 300 & 71.8 \\
\hline \multirow{2}{*}{$\begin{array}{l}\text { Number of ARV drug doses missed in the last } 7 \\
\text { days }\end{array}$} & $\leq 2$ doses & 64 & 54.2 \\
\hline & $\geq 3$ doses & 54 & 45.8 \\
\hline \multirow[t]{2}{*}{ Number of ARV drugs doses missed in the last 3 days } & $\leq 2$ doses & 41 & 56.2 \\
\hline & $\geq 3$ doses & 32 & 43.8 \\
\hline \multirow[t]{4}{*}{ Reasons for nonadherence to ART } & Illness & 13 & 11.0 \\
\hline & Transportation & 26 & 22.0 \\
\hline & $\begin{array}{l}\text { Refusal to take the } \\
\text { drugs }\end{array}$ & 16 & 13.6 \\
\hline & Forgetfulness & 63 & 53.4 \\
\hline
\end{tabular}

Factors associated with adherence to ART: Different socio-demographic and adherence related variables were entered in stepwise regression. Crude analysis showed that residence, distance from the health facility, disclosure of HIV status to families, encounter of drug side effect, having history of opportunistic infections, and current CD4 count were negatively associated with adherence to ARV drugs $(p<0.05)$. In multivariate logistic regression analysis, only disclosure HIV status to families (AOR: 0.12, 95\% CI: $0.05-0.58 ; \mathrm{P}<0.001)$ and encounter of drug side effect (AOR: 2.69, 95\% CI: 1.27-5.05; $\mathrm{p}<0.001)$ were factors that negatively affected the respondents' adherence to ARV drugs (Table 4).

\section{DISCUSSION}

This study assessed patients' ART adherence level and the factors associated with their ART adherence in Hara Town and its surroundings, North-Eastern Ethiopia. The adherence rate was found to be $71.8 \%$ in the past seven days of respondents' recall of missed doses. Our result was below the recommended level of good adherence. It must be $(\geq 95 \%)$ to suppress the viral load for a long time (8), to bring the patients' clinical improvement and increased pateint's CD4 count $(24,25)$

This finding revealed a very low adherence level as compared to similar studies in Ethiopia: Gondar (85.3\%) (10), Addis Ababa (73.3\%) (26), Harar and Dire Dawa (85\%) (27), Debre Berhan (95.5\%) (28), Gondar (82.7\%) (29), Jimma (94.3\%) (30), and Jimma (95\%) (31). The possible reason for this might be due to the difference in socio-demographic characteristics of participants, and the service quality discrepancy. This result is also lower than other studies conducted in some African countries: Uganda (97\%), Namibia (86.1\%), and Cameron (76.7\% males vs $90.84 \%$ females) (24). However, this figure was higher than the study conducted in Ghana, 62.2\% (32), rural Zambia $(59.9 \%) \quad(33)$, Nigeria $(70.8 \%) \quad(17)$, and Botswana (54\%) (34). The low adherence rate

DOI: http://dx.doi.org/10.4314/ejhs.v29i2.2 
reported from the above studies might be due to different population characteristics, health service quality, study settings, and the adherence level measurements used.

Table 4: Bivariate and multivariate analysis showing factors associated with adherence to ARV drugs in Hara Town and its surroundings, April to May $2017(\mathrm{n}=418)$

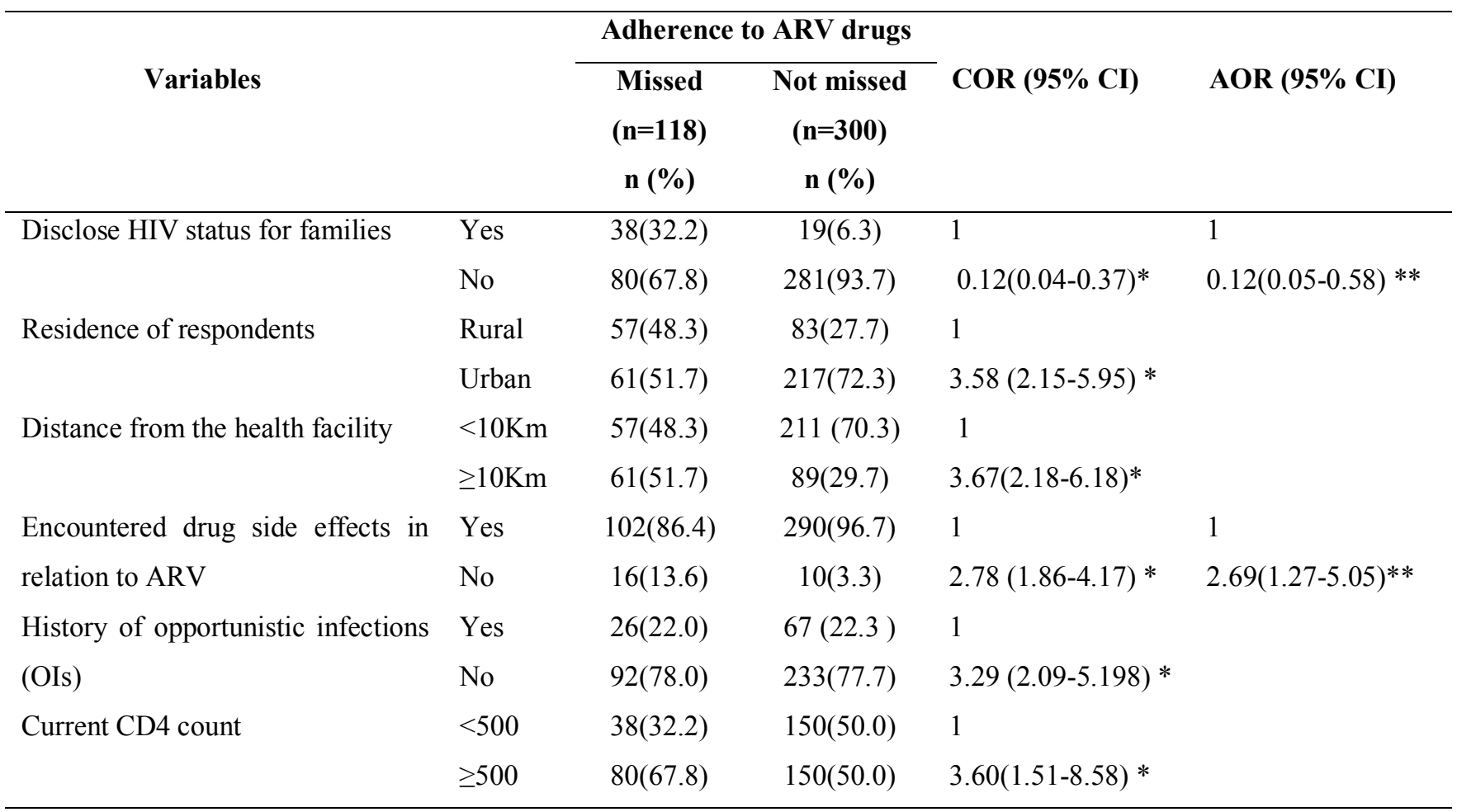

$* P<0.05 ; * * P<0.001 ; 1=$ constant

In our study, the majority, 63(53.4\%) of the respondents reported that forgetfulness was the reason for their nonadherence followed by the transportation problem to the ART-clinic 26 (22\%). From predicted associated factors, only respondents who did not disclose their HIV status to their families were $88 \%$ less likely to adhere as compared to those who had disclosed their HIV status (AOR: 0.12, 95\% CI: 0.05-0.58). A similar findings were reported from Harar and Dire Dawa, Ethiopia, showing that patients who did not disclose their HIV status to their families were $55 \%$ less likely to adhere to their medication than those who disclosed their HIV status (AOR: 0.45; 95\% CI: 0.21-0.97) (35). This implies that there was still fear of stigma and discrimination to disclose their HIV status to their families.

In this finding, drug side effect was another factor which was associated with particpants' adherence to their ART medication. Respondents who had not encountered drug side effect were 2.69 times more likely to adhere to their ART medication than those who had experienced drug side effect (AOR: 2.69, 95\%CI: 1.27-5.05). Incomparable to this, another study conducted in Gondar, Ethiopia, reported that respondents with drug side effect were $70 \%$ less likely to adhere to ARV therapy than those who did not encounter drug side effect (AOR: 0.3, 95\%CI: 0.2-0.5) (10). Another study which was done in the Kathmandu District, Nepal, reported that the odds of adherence among those who did not experience drug side effects were 4.88 times higher than those who reported experiencing drug side effects (36). The severity of drug side effects varies from mild to life threating condition. Therefore, instead of droping out their medication, it is recommended to get a consultation with the

DOI: http://dx.doi.org/10.4314/ejhs.v29i2.2 
healthcare providers to manage the adverse consequence of the ARV drugs.

In this study, a very low ART adherence level was reported. Intervention measures to promote ART adherence in the study area should get attention. These include revising counseling policy to investigate patients' drug side effect and health education programs to enable HIV positive individuals to disclose their HIV status to their families and to deal with drug side effects.

\section{ACKNOWLEDGMENTS}

We are grateful to Woldia University, Faculty of Health Sciences for approving of this study and providing with the ethical clearance. We would also like to thank all study participants for their commitment to responding to our interview. Our appreciation also goes to the supervisor, data collectors, and all staff at Hara Town ART Clinic.

\section{REFERENCES}

1. MONDAL M, SHITAN M. FACTORS AFFECTING THE HIV/AIDS EPIDEMIC: AN ECOLOGICAL ANALYSIS OF GLOBAL DATA. AFRICAN HEALTH SCIENCES. 2013;13(2):301-10.

2. JOINT UNITED NATIONS PROGRAMME ON HIV/AIDS. WORLD AIDS DAY REPORT 2011. GENEVA, SWITZERLAND: UNAIDS. 2011.

3. WHO. THE GLOBAL HEALTH SECTOR STRATEGY ON HIV/AIDS 2011-2015: AN INTERIM REVIEW OF PROGRESS: ABRIDGED REPORT, MAY 2014.

4. WHO. CONSOLIDATED GUIDELINES ON THE USE OF ANTIRETROVIRAL DRUGS FOR TREATING AND PREVENTING HIV INFECTION: RECOMMENDATIONS FOR A PUBLIC HEALTH APPROACH: WORLD HEALTH ORGANIZATION; 2016.

5. WHO. GLOBAL UPDATE ON HIV TREATMENT 2013: RESULTS, IMPACT AND OPPORTUNITIES: WHO REPORT IN PARTNERSHIP WITH UNICEF AND UNAIDS 2013.
6. COHEN MS, CHEN YQ, MCCAULEY M, GAMBLE T, HOSSEINIPOUR MC, KUMARASAMY N, ET AL. PREVENTION OF HIV-1 INFECTION WITH EARLY ANTIRETROVIRAL THERAPY. NEW ENGLAND JOURNAL OF MEDICINE. 2011;365(6):493-505.

7. OBIRIKORANG C, SELLEH PK, ABLEDU JK, FOFIE CO. PREDICTORS OF ADHERENCE TO ANTIRETROVIRAL THERAPY AMONG HIV/AIDS PATIENTS IN THE UPPER WEST REGION OF GHANA. ISRN AIDS. 2013.

8. ANURADHA S, JOSHI A, NEGI M, NISCHAL N, RAJESHWARI K, DEWAN R. FACTORS INFLUENCING ADHERENCE TO ART: NEW INSIGHTS FROM A CENTER PROVIDING FREE ART UNDER THE NATIONAL PROGRAM IN DELHI, INDIA. $J$ INT ASSOC PROVID AIDS CARE. 2013;12(3):195-201.

9. EDELMAN EJ, GORDON KS, GLOVER J, MCNICHOLL IR, FIELLIN DA, JUSTICE AC. THE NEXT THERAPEUTIC CHALLENGE IN HIV: POLYPHARMACY. DRUGS \& AGING. 2013;30(8):613-28.

10. TADESSE S, TADESSE A, WUBSHET M. ADHERENCE TO ANTIRETROVIRAL TREATMENT AND ASSOCIATED FACTORS AMONG PEOPLE LIVING WITH HIV/AIDS IN NORTHWEST ETHIOPIA. J TROP DIS. 2014;2(133):2.

11. FEDERAL HIV/AIDS PREVENTION AND CONTROL OFFICE, FEDERAL MINISTRY OF HEALTH. GUIDELINE FOR MANAGEMENT OF OPPORTUNISTIC INFECTION AND ANTIRETROVIRAL TREATMENT IN ADOLESCENTS AND ADULTS IN ETHIOPIA. 2007;2(13).

12. FEDERAL HIV/AIDS PREVENTION AND CONTROL OFFICE, FEDERAL MINISTRY OF HEALTH: SINGLE POINT HIV PREVALENCE ESTIMATE. 2007, ETHIOPIA. 
13. WHO. ETHIOPIA | HIV/AIDS. WHO ETHIOPIA, 2014. ACCESSED MARCH 2018.

14. SANDERS R. EQUITY AND ACCESS TO ART IN ETHIOPIA: ACTIVITY REPORT. WASHINGTON, DC: FUTURES GROUP, HEALTH POLICY INITIATIVE, TASK ORDER 1. 2010.

15. AMICO KR, HARMAN JJ, JOHNSON BT. EFFICACY OF ANTIRETROVIRAL THERAPY ADHERENCE INTERVENTIONS: A RESEARCH SYNTHESIS OF TRIALS, 1996 TO 2004. JAIDS. 2006;41(3):285-97.

16. CAMPBELL C, SCOTT K, MADANHIRE C, NYAMUKAPA C, GREGSON S. A 'GOOD HOSPITAL': NURSE AND PATIENT PERCEPTIONS OF GOOD CLINICAL CARE FOR HIV-POSITIVE PEOPLE ON ANTIRETROVIRAL TREATMENT IN RURAL ZIMBABWE-A MIXED-METHODS QUALITATIVE STUDY. INTERNATIONAL JOURNAL OF NURSING STUDIES. 2011;48(2):175-83.

$\begin{array}{lll}\text { 17. SALAMI AK, } & \text { FADEYI } & \text { A, } \\ \text { OGUNMODEDE JA, DESALU } & \text { O. }\end{array}$ FACTORS INFLUENCING ADHERENCE TO ANTIRETROVIRAL MEDICATION IN ILORIN, NIGERIA. JOURNAL OF THE INTERNATIONAL ASSOCIATION OF PHYSICIANS IN AIDS CARE. 2010;9(3):1915.

18. PRESS N, TYNDALL MW, WOOD E, HOGG RS, MONTANER J. VIROLOGIC AND IMMUNOLOGIC RESPONSE, CLINICAL PROGRESSION, AND HIGHLY ACTIVE ANTIRETROVIRAL THERAPY ADHERENCE. JOURNAL OF ACQUIRED IMMUNE DEFICIENCY SYNDROMES (1999). 2002;31:S112-7.

19. CHAIYACHATI KH, OGBUOJI O, PRICE $\mathrm{M}$, SUTHAR AB, NEGUSSIE EK, BÄRNIGHAUSEN T. INTERVENTIONS TO IMPROVE ADHERENCE TO ANTIRETROVIRAL THERAPY: A RAPID SYSTEMATIC REVIEW. AIDS. 2014;28:S187-S204.

20. AMICO KR. EVIDENCE FOR TECHNOLOGY INTERVENTIONS TO
PROMOTE ART ADHERENCE IN ADULT POPULATIONS: A REVIEW OF THE LITERATURE 2012-2015. CURR HIV/AIDS REP. 2015;12(4):441-50.

21. HANSANA V, SANCHAISURIYA P, DURHAM J, SYCHAREUN V, CHALEUNVONG K, BOONYALEEPUN S, ET AL. ADHERENCE TO ANTIRETROVIRAL THERAPY (ART) AMONG PEOPLE LIVING WITH HIV (PLHIV): A CROSS-SECTIONAL SURVEY TO MEASURE IN LAO PDR. BMC PUBLIC HEALTH. 2013;13:617.

22. WHO. THE HIV DRUG RESISTANCE REPORT. WORLD HEALTH ORGANIZATION, GENEVA, SWITZERLAND. 2012. REPORT NO.: 9241503939.

23. CHESNEY MA, ICKOVICS J, CHAMBERS D, GIFFORD A, NEIDIG J, ZWICKL B, ET AL. SELF-REPORTED ADHERENCE TO ANTIRETROVIRAL MEDICATIONS AMONG PARTICIPANTS IN HIV CLINICAL TRIALS: THE AACTG ADHERENCE INSTRUMENTS. AIDS CARE. 2000;12(3):255-66.

24. FONSAH JY, NJAMNSHI AK, KOUANFACK C, QIU F, NJAMNSHI DM, TAGNY CT, ET AL. ADHERENCE TO ANTIRETROVIRAL THERAPY (ART) IN YAOUNDE-CAMEROON: ASSOCIATION WITH OPPORTUNISTIC INFECTIONS, DEPRESSION, ART REGIMEN AND SIDE EFFECTS. PLOS ONE. 2017;12(1):E0170893.

25. WHO. SCALING UP ANTIRETROVIRAL THERAPY IN RESOURCE-LIMITED SETTINGS: GUIDELINES FOR A PUBLIC HEALTH APPROACH: EXECUTIVE SUMMARY. GENEVA: WORLD HEALTH ORGANIZATION; 2002.

26. MENGISTU Z, CHERE A. ADHERENCE TO ANTIRETROVIRAL THERAPY AND ITS ASSOCIATED FACTORS AMONG PEOPLE LIVING WITH HIV/AIDS IN ADDIS ABABA, ETHIOPIA. ETHIOP MED J. 2012;50(4):355-61.

27. LETTA S, DEMISSIE A, OLJIRA L, DESSIE Y. FACTORS ASSOCIATED 
WITH ADHERENCE TO ANTIRETROVIRAL THERAPY (ART) AMONG ADULT PEOPLE LIVING WITH HIV AND ATTENDING THEIR CLINICAL CARE, EASTERN ETHIOPIA. BMC INT HEALTH HUM RIGHTS. 2015;15:33.

28. KETEMA AK, SHEWANGIZAW WERET Z. ASSESSMENT OF ADHERENCE TO HIGHLY ACTIVE ANTIRETROVIRAL THERAPY AND ASSOCIATED FACTORS AMONG PEOPLE LIVING WITH HIV AT DEBREBRIHAN REFERRAL HOSPITAL AND HEALTH CENTER, NORTHEAST ETHIOPIA: A CROSS-SECTIONAL STUDY. HIV AIDS (AUCKL). 2015;7:75-81.

29. TESSEMA B, BIADGLEGNE F, MULU A, GETACHEW A, EMMRICH F, SACK U. MAGNITUDE AND DETERMINANTS OF NONADHERENCE AND NONREADINESS TO HIGHLY ACTIVE ANTIRETROVIRAL THERAPY AMONG PEOPLE LIVING WITH HIV/AIDS IN NORTHWEST ETHIOPIA: A CROSSSECTIONAL STUDY. AIDS RESEARCH AND THERAPY. 2010;7(1):2.

30. AMBERBIR A, WOLDEMICHAEL K, GETACHEW S, GIRMA B, DERIBE $\mathrm{K}$. PREDICTORS OF ADHERENCE TO ANTIRETROVIRAL THERAPY AMONG HIV-INFECTED PERSONS: A PROSPECTIVE STUDY IN SOUTHWEST ETHIOPIA. BMC PUBLIC HEALTH. 2008;8:265.

31. TIYOU A, BELACHEW T, ALEMSEGED F, BIADGILIGN S. PREDICTORS OF ADHERENCE TO ANTIRETROVIRAL THERAPY AMONG PEOPLE LIVING WITH HIV/AIDS IN RESOURCELIMITED SETTING OF SOUTHWEST ETHIOPIA. AIDS RESEARCH AND THERAPY. 2010;7:39.

32. OBIRIKORANG C, SELLEH PK, ABLEDU JK, FOFIE CO. PREDICTORS OF
ADHERENCE TO ANTIRETROVIRAL THERAPY AMONG HIV/AIDS PATIENTS IN THE UPPER WEST REGION OF GHANA. ISRN AIDS. 2013;2013.

33. SASAKI Y, KAKIMOTO K, DUBE C, SIKAZWE I, MOYO C, SYAKANTU G, ET AL. ADHERENCE TO ANTIRETROVIRAL THERAPY (ART) DURING THE EARLY MONTHS OF TREATMENT IN RURAL ZAMBIA: INFLUENCE OF DEMOGRAPHIC CHARACTERISTICS AND SOCIAL SURROUNDINGS OF PATIENTS. ANN CLIN MICROBIOL ANTIMICROB. 2012;11:34.

34. WEISER S, WOLFE W, BANGSBERG D, THIOR I, GILBERT P, MAKHEMA J, ET AL. BARRIERS TO ANTIRETROVIRAL ADHERENCE FOR PATIENTS LIVING WITH HIV INFECTION AND AIDS IN BOTSWANA. JAIDS. 2003;34(3):281-8.

35. LETTA S, DEMISSIE A, OLJIRA L, DESSIE Y. FACTORS ASSOCIATED WITH ADHERENCE TO ANTIRETROVIRAL THERAPY (ART) AMONG ADULT PEOPLE LIVING WITH HIV AND ATTENDING THEIR CLINICAL CARE, EASTERN ETHIOPIA. BMC INTERNATIONAL HEALTH AND HUMAN RIGHTS. 2015;15(1):33.

36. SHIGDEL R. FACTORS ASSOCIATED WITH ADHERENCE TO ANTIRETROVIRAL THERAPY IN HIVINFECTED PATIENTS: A CROSSSECTIONAL STUDY IN KATHMANDU DISTRICT, NEPAL. NEPAL: UNIVERSITY OF TROMSØ; 2012. 